\title{
Alginate oligosaccharide-induced intestinal morphology, barrier function and epithelium apoptosis modifications have beneficial effects on the growth performance of weaned pigs
}

\author{
Jin Wan ${ }^{\dagger}$, Jiao Zhang ${ }^{\dagger}$, Daiwen Chen, Bing Yu, Xiangbing Mao, Ping Zheng, Jie Yu, Junqiu Luo and Jun He (i)
}

\begin{abstract}
Background: Alginate oligosaccharide (AOS), produced from alginate by alginate lyase-mediated depolymerisation, is a potential substitute for antibiotics and possesses growth-enhancing effects. Nevertheless, the mechanisms by which AOS regulates porcine growth remain to be elucidated. Therefore, we investigated the AOS-mediated changes in the growth performance of weaned pigs by determining the intestinal morphology, barrier function, as well as epithelium apoptosis.

Methods: Twenty-four weaned pigs were distributed into two groups $(n=12)$ and received either a basal diet (control group) or the same diet supplemented with $100 \mathrm{mg} / \mathrm{kg} \mathrm{AOS}$. On d 15, D-xylose (0.1 g/kg body weight) was orally administrated to eight randomly selected pigs per treatment, and their serum and intestinal mucosa samples were collected $1 \mathrm{~h}$ later.

Results: Our results showed that inclusion of AOS in the diet for 2 wk increased $(P<0.05)$ the average daily body weight gain in weaned pigs. Notably, AOS supplementation ameliorated the intestinal morphology and barrier function, as suggested by the enhanced $(P<0.05)$ intestinal villus height, secretory immunoglobulin A content and goblet cell counts. Compared to the control group, AOS ingestion both decreased $(P<0.05)$ the total apoptotic percentage and increased $(P<0.05)$ the proportion of $S$ phase in the intestinal epithelial cells. Furthermore, AOS not only up-regulated $(P<0.05)$ the B-cell lymphoma-2 $(B C L 2)$ transcriptional level but also down-regulated $(P<0.05)$ the B-cell lymphoma-2-associated X protein (BAX), cysteinyl aspartate-specific proteinase-3 (caspase-3) and caspase-9 transcriptional levels in the small intestine.

Conclusions: In summary, this study provides evidence that supplemental AOS beneficially affects the growth performance of weaned pigs, which may result from the improved intestinal morphology and barrier function, as well as the inhibited enterocyte death, through reducing apoptosis via mitochondria-dependent apoptosis.
\end{abstract}

Keywords: Alginate oligosaccharide, Barrier function, Cell apoptosis, Intestinal morphology, Weaned pigs

\footnotetext{
* Correspondence: hejun8067@163.com

${ }^{\dagger}$ Jin Wan and Jiao Zhang contributed equally to this work.

Institute of Animal Nutrition, Sichuan Agricultural University, Chengdu

611130, Sichuan, People's Republic of China
}

(c) The Author(s). 2018 Open Access This article is distributed under the terms of the Creative Commons Attribution 4.0 International License (http://creativecommons.org/licenses/by/4.0/), which permits unrestricted use, distribution, and reproduction in any medium, provided you give appropriate credit to the original author(s) and the source, provide a link to the Creative Commons license, and indicate if changes were made. The Creative Commons Public Domain Dedication waiver (http://creativecommons.org/publicdomain/zero/1.0/) applies to the data made available in this article, unless otherwise stated. 


\section{Background}

Weaning is one of the most significant events in the life of pigs as they are abruptly forced to adapt to nutritional, immunological and psychological disruptions [1]. The weaning transition of piglets is commonly accompanied by growth retardation and impaired intestinal barrier [2-4]. Studies have also indicated that weaning can disrupt the physiological oxidant and antioxidant equilibrium and lead to oxidative stress $[5,6]$, eventually inducing epithelium apoptosis and cell cycle arrest in the small intestine of post-weaning piglets [7]. Over the past decades, antibiotic medication has proven an effective preventative and treatment method, used worldwide to treat these issues. However, the widespread use of antibiotics has led, at least in part, to bacterial resistance, resulting in the delayed administration of effective therapy, as well as morbidity and mortality in both humans and animals [8-10]. Hence, numerous antibiotic alternatives have been investigated, among which oligosaccharides have attracted considerable research interest, due to their health benefits in weaned pigs $[11,12]$.

Alginate, a naturally occurring anionic polysaccharide that is extracted from marine brown algae, is composed of two types of uronic acid monomers, distributed as blocks of 1,4-linked $\beta$ - $D$-mannuronic acid (M) or $\alpha$ - $L$-guluronic acid $(G)$, as well as heteropolymeric mixed sequences (M-G, usually alternating) [13, 14]. Alginate oligosaccharide (AOS), prepared by depolymerising alginate, is a non-immunogenic, non-toxic, biodegradable polymer with reported multifarious biological properties [15], including anti-oxidation [16], anti-apoptotic [17], anti-inflammatory [18] and anti-tumour effects [19]. These beneficial properties of AOS suggest it may be an effective dietary ingredient, yet the use of AOS as a food supplement for humans or animals is contemporarily still in its infancy. Although emerging evidence identified that AOS supplements favourably enhanced the growth performance in piglets after weaning [20], the AOS mechanisms responsible for this benefit are poorly understood. As such, further elucidation is meaningful and essential.

Accordingly, the present study was performed to explore the effects of AOS supplementation on the intestinal architecture, barrier function and epithelium apoptosis in weaned pigs, aiming to provide partial theoretical evidence for the mechanisms by which AOS enhances growth performance of weaned pigs. It is anticipated that our findings will pave the way for developing AOS as a functional food for both humans and animals in the near future.

\section{Methods}

Animal care and experimental design

Initially, 24 pigs (Duroc $\times$ Landrace $\times$ Yorkshire), weaned at $21 \mathrm{~d}$ and with an average body weight (BW) of
$(6.21 \pm 0.09) \mathrm{kg}$, were assigned to two treatments with 12 replicates per treatment. The treatment groups including a control group (CON), in which pigs were fed a basal diet, and an AOS group, in which pigs were fed a basal diet supplemented with $100 \mathrm{mg} / \mathrm{kg}$ AOS (provided by the Dalian Institute of Chemical Physics, Chinese Academy of Sciences, Dalian, China). The basal diet was formulated to meet or exceed the nutrient requirements recommended by the National Research Council (Table 1) [21]. During the 14-day experimental period, all pigs were individually housed in metabolism cages $(0.7 \mathrm{~m} \times 1.5 \mathrm{~m})$ in a temperature- $\left(24-26{ }^{\circ} \mathrm{C}\right)$, humidity$(65 \% \pm 5 \%)$ and light-controlled room and were given ad libitum access to feed and water.

Table 1 Ingredients and nutrient composition of the basal diet

\begin{tabular}{|c|c|c|c|}
\hline Ingredient & Content, \% & $\begin{array}{l}\text { Nutrient } \\
\text { composition }^{c}\end{array}$ & Content, \% \\
\hline Corn (7.8\% crude protein) & 28.80 & $\begin{array}{l}\text { Digestible energy, } \\
\text { MJ/kg }\end{array}$ & 14.85 \\
\hline $\begin{array}{l}\text { Extruded corn (7.8\% crude } \\
\text { protein) }\end{array}$ & 26.00 & Crude protein & 19.35 \\
\hline $\begin{array}{l}\text { Soybean meal ( } 44.2 \% \\
\text { crude protein) }\end{array}$ & 11.00 & Calcium & 0.83 \\
\hline Extruded soybean & 10.00 & Total phosphorus & 0.60 \\
\hline $\begin{array}{l}\text { Whey powder (low } \\
\text { protein) }\end{array}$ & 7.00 & $\begin{array}{l}\text { Available } \\
\text { phosphorus }\end{array}$ & 0.43 \\
\hline $\begin{array}{l}\text { Soybean protein } \\
\text { concentrate }\end{array}$ & 5.00 & Lysine & 1.37 \\
\hline $\begin{array}{l}\text { Fish meal ( } 62.5 \% \text { crude } \\
\text { protein) }\end{array}$ & 4.00 & Methionine & 0.49 \\
\hline Sucrose & 4.00 & $\begin{array}{l}\text { Methionine + } \\
\text { Cysteine }\end{array}$ & 0.76 \\
\hline Soybean oil & 1.50 & Threonine & 0.81 \\
\hline Limestone & 0.75 & Tryptophan & 0.22 \\
\hline Dicalcium phosphate & 0.60 & & \\
\hline L-Lysine-HCl (78\%) & 0.40 & & \\
\hline $\mathrm{NaCl}$ & 0.30 & & \\
\hline DL-Methionine & 0.18 & & \\
\hline L-Threonine (98.5\%) & 0.10 & & \\
\hline Chloride choline & 0.10 & & \\
\hline Tryptophan (98\%) & 0.02 & & \\
\hline Vitamin premix ${ }^{a}$ & 0.05 & & \\
\hline Mineral premix ${ }^{b}$ & 0.20 & & \\
\hline Total & 100 & & \\
\hline
\end{tabular}

${ }^{a}$ The vitamin premix provided the following per kg of diets: 6,000 IU vitamin (V) $A, 3,000 \mathrm{IU} \mathrm{VD}_{3}, 24 \mathrm{mg} \mathrm{VE}, 3 \mathrm{mg} \mathrm{VK}, 1.5 \mathrm{mg} \mathrm{VB}{ }_{1}, 6 \mathrm{mg} \mathrm{VB}{ }_{2}, 3 \mathrm{mg} \mathrm{VB}{ }_{6}$, $0.02 \mathrm{mg} \mathrm{V} \mathrm{B}_{12}, 14 \mathrm{mg}$ niacin, $15 \mathrm{mg}$ pantothenic acid, $1.2 \mathrm{mg}$ folic acid and $0.15 \mathrm{mg}$ biotin

${ }^{\mathrm{b}}$ The mineral premix provided the following per kg of diets: $100 \mathrm{mg} \mathrm{Fe}, 6 \mathrm{mg}$ $\mathrm{Cu}, 100 \mathrm{mg} \mathrm{Zn}, 4 \mathrm{mg} \mathrm{Mn}, 0.30 \mathrm{mg} \mathrm{I}$ and $0.35 \mathrm{mg}$ Se

'Values are calculated composition 


\section{Growth performance assessment}

At the start and end of the experiment, the pigs were individually weighed before feeding, and daily feed consumption per pig was measured throughout the study. Growth performance indices, including average daily body weight gain (ADG), average daily feed intake (ADFI) and the gain-to-feed ratio (G:F), were subsequently determined for each group from the data obtained.

\section{Sample collection}

On the morning of $\mathrm{d} 15$, after overnight starvation, eight pigs from each treatment were randomly selected and orally infused with $D$-xylose at the dose of $0.1 \mathrm{~g} / \mathrm{kg} \mathrm{BW}$ $[22,23]$. After infusion of $D$-xylose (1 h), blood samples were collected by jugular vein puncture and placed in $10-\mathrm{mL}$ vacuum tubes (non-anticoagulant). The samples were centrifuged at $3,500 \times g, 4{ }^{\circ} \mathrm{C}$ for $15 \mathrm{~min}$, to acquire serum, and stored at $-20{ }^{\circ} \mathrm{C}$, until measurement of $D$-xylose concentration.

After blood sampling, the same pigs were anaesthetised with an intravenous injection of sodium pentobarbital (200 mg/kg BW), and the tissues of the duodenum, jejunum and ileum were immediately isolated [24]. Approximately $5-\mathrm{cm}$ duodenal, jejunal and ileal middle segments were gently flushed with ice-cold phosphate buffered saline (PBS), followed by fixation in PBS for flow cytometry or in $4 \%$ paraformaldehyde solution for morphological and immunohistochemical analyses. Finally, the residual duodenal, jejunal and ileal segments were scraped with a scalpel blade, and the collected mucosa stored at $-80{ }^{\circ} \mathrm{C}$ for quantitative real-time polymerase chain reaction (qPCR) analysis.

\section{Serum $D$-xylose determination}

Serum $D$-xylose was quantitated using a $D$-xylose assay kit (Nanjing Jiancheng Bioengineering Institute, Nanjing, China), by following the manufacturer's protocols. The absorbance of the reaction mixture was acquired spectrophotometrically at $554 \mathrm{~nm}$, using a multi-mode microplate reader (SpectraMax M2, Molecular Devices, Sunnyvale, CA, USA). $D$-Xylose concentration was presented as milligrams per litre of serum $(\mathrm{mg} / \mathrm{L})$.

\section{Histomorphological analysis and cell counting}

One-cm long duodenal, jejunal and ileal samples were dehydrated through a graded series of ethanol and embedded in paraffin. Cross-sections of each sample were prepared, stained with haematoxylin and eosin (H\&E), and then sealed with neutral resin. Ultrathin sections of the duodenal, jejunal and ileal samples were examined for villus height, villus width and crypt depth, using an image processing and analysis system (Image-Pro Plus 6.0, Media Cybernetics, Inc., Bethesda, MD, USA).
Afterwards, the goblet cell and columnar cell counts per villus were also assessed. Villus height was recorded as the distance from the tip of the villi to the villus-crypt junction, and width was measured at half of the villus height [25]. Crypt depth was expressed as the invaginated depth between adjacent villi. A total of 10 intact, well-oriented, crypt-villus units were analysed in triplicate per intestinal segment. The values obtained from 10 villi, in triplicate by each intestinal segment, were averaged. The villus height-to-crypt depth ratio was computed from the measurements obtained above, and the villus surface area $\left(\mathrm{mm}^{2}\right)$ was calculated by multiplying $2 \pi$ (villus width/2) by the villus height [26].

\section{Immunohistochemistry}

For immunohistochemistry, the paraformaldehyde-fixed duodenal, jejunal and ileal samples were embedded in paraffin and sectioned into $2 \mu \mathrm{m}$ thickness, then collected on glass slides. After deparaffinisation and hydration, the sections were pre-treated with $3 \% \mathrm{H}_{2} \mathrm{O}_{2}$ in methanol at room temperature for $10 \mathrm{~min}$, to quench endogenous peroxidase activity and, then, heated in $10 \mathrm{mmol} / \mathrm{L}$ citrate buffer $(\mathrm{pH}$ 6.0) to retrieve the antigen. After several rinses in PBS, the sections were blocked with $10 \%$ goat serum at room temperature for $20 \mathrm{~min}$, to eliminate non-specific antibody binding and then incubated overnight at $4{ }^{\circ} \mathrm{C}$ with 1:200 dilution of rabbit anti-secretory immunoglobulin A (sIgA) antibody (Beijing Biosynthesis Biotechnology Co., Ltd., Beijing, China). After rinsing with PBS several times, the sections were incubated with biotinylated goat anti-rabbit IgG secondary antibody (Beijing Zhongshan Golden Bridge Biotechnology Co., Ltd., Beijing, China) at $37{ }^{\circ} \mathrm{C}$ for $30 \mathrm{~min}$. After rinsing several times in PBS, immunodetection was conducted, using 3,3'-diaminobenzidine $(\mathrm{DAB})$ as the chromogen. The sections were counterstained with haematoxylin and mounted in neutral resin. For each section in the Motic BA210 digital microscope (Motic China Group Co., Ltd., Xiamen, China), five fields of vision were randomly selected, with a fixed window area. The integrated optical density of sIgA in the duodenal, jejunal and ileal mucosa was detected by using Image-Pro Plus 6.0 image analysis system (Media Cybernetics, Inc), and the sIgA protein expression was reflected by the mean value of the integrated optical density.

\section{Enterocyte apoptosis detection}

Duodenal, jejunal and ileal epithelial cells were isolated, to measure the proportion of apoptotic cells by flow cytometry with a PE Annexin V Apoptosis Detection Kit I (Becton, Dickinson and Company, BD Biosciences, San Jose, CA, USA) [27]. Briefly, the excised mucosal layer of the duodenum, jejunum and ileum were isolated, and 
Table 2 Primer sequences for quantitative real-time polymerase chain reaction

\begin{tabular}{|c|c|c|c|}
\hline Gene $^{a}$ & Primer sequence $\left(5^{\prime} \rightarrow 3^{\prime}\right)$ & Size, bp & Accession No. \\
\hline MUC1 & $\begin{array}{l}\text { Forward: GTGCCGCTGCCCACAACCTG } \\
\text { Reverse: AGCCGGGTACCCCAGACCCA }\end{array}$ & 141 & XM_001926883.4 \\
\hline MUC2 & $\begin{array}{l}\text { Forward: GGTCATGCTGGAGCTGGACAGT } \\
\text { Reverse: TGCCTCCTCGGGGTCGTCAC }\end{array}$ & 181 & XM_013989745.1 \\
\hline MUC4 & $\begin{array}{l}\text { Forward: GATGCCCTGGCCACAGAA } \\
\text { Reverse: TGATTCAAGGTAGCATTCATTTGC }\end{array}$ & 89 & XM_001926442.1 \\
\hline BAX & $\begin{array}{l}\text { Forward: CTGACGGCAACTTCAACTGG } \\
\text { Reverse: CGTCCCAAAGTAGGAGAGGA }\end{array}$ & 200 & XM_003127290.4 \\
\hline$B C L 2$ & $\begin{array}{l}\text { Forward: AGCATGCGGCCTCTATTTGA } \\
\text { Reverse: GGCCCGTGGACTTCACTTAT }\end{array}$ & 120 & XM_003121700.2 \\
\hline FAS & $\begin{array}{l}\text { Forward: TGATGCCCAAGTGACTGACC } \\
\text { Reverse: GCAGAATTGACCCTCACGAT }\end{array}$ & 103 & NM_213839.1 \\
\hline caspase-3 & $\begin{array}{l}\text { Forward: GTGGGACTGAAGATGACA } \\
\text { Reverse: ACCCGAGTAAGAATGTG }\end{array}$ & 190 & NM_214131.1 \\
\hline caspase-8 & $\begin{array}{l}\text { Forward: AGACAAGGGCATCATCATCGG } \\
\text { Reverse: GGTITACCAAGAAGGGAACGG }\end{array}$ & 102 & NM_001031779.2 \\
\hline caspase-9 & $\begin{array}{l}\text { Forward: AATGCCGATTTGGCTTACGT } \\
\text { Reverse: CATTTGCTTGGCAGTCAGGTT }\end{array}$ & 195 & XM_003127618.4 \\
\hline GAPDH & $\begin{array}{l}\text { Forward: ATGGTGAAGGTCGGAGTGAAC } \\
\text { Reverse: CTCGCTCCTGGAAGATGGT }\end{array}$ & 235 & NM_001206359.1 \\
\hline
\end{tabular}

${ }^{a} M U C 1$, mucin 1; MUC2, mucin 2; MUC4, mucin 4; BAX, B-cell lymphoma-2-associated X protein; BCL2, B-cell lymphoma-2; caspase-3, cysteinyl aspartate-specific proteinase-3; caspase-8, cysteinyl aspartate-specific proteinase-8; caspase-9, cysteinyl aspartate-specific proteinase-9; GAPDH,

glyceraldehyde-3-phosphate dehydrogenase

then, ground and filtered to form a cell suspension. The cells were carefully washed twice with ice-cold PBS and suspended in the PBS at $1 \times 10^{6}$ cells $/ \mathrm{mL}$. After adding $5 \mu \mathrm{L}$ of PE Annexin $\mathrm{V}$ and $5 \mu \mathrm{L}$ of 7 -aminoactinomycin $\mathrm{D}$ (7-AAD) to a $100-\mu \mathrm{L}$ aliquot of the cell suspension, the mixture was incubated at room temperature for $15 \mathrm{~min}$ in a dark room. Afterwards, $400 \mu \mathrm{L}$ of Annexin $\mathrm{V}$ Binding Buffer $(1 \times)$ was added, and the apoptotic cells were examined by flow cytometry (CytoFlex, Beckman Coulter, Inc., Brea, CA, USA) within $1 \mathrm{~h}$.

Table 3 Effects of alginate oligosaccharide on the growth performance of weaned pigs throughout the entire experimental period ${ }^{a}$

\begin{tabular}{llll}
\hline Item $^{c}$ & Treatment $^{\mathrm{b}}$ & & $\begin{array}{l}P \text { - } \\
\text { value }\end{array}$ \\
\cline { 2 - 3 } & CON & AOS & 0.973 \\
\hline Initial BW, kg & $6.20 \pm 0.09$ & $6.21 \pm 0.08$ & 0.009 \\
Final BW, kg & $8.73 \pm 0.16$ & $9.46 \pm 0.20^{* *}$ & \\
D 1-14 & & & \\
ADG, g/d & $180.36 \pm 9.70$ & $232.44 \pm 13.51^{* *}$ & 0.005 \\
ADFl, g/d & $253.12 \pm 11.75$ & $311.61 \pm 19.64^{*}$ & 0.018 \\
G:F & $0.72 \pm 0.02$ & $0.75 \pm 0.02$ & 0.213 \\
\hline
\end{tabular}

${ }^{*} P<0.05$ versus the CON group. ${ }^{* *} P<0.01$ versus the CON group

${ }^{\mathrm{a}}$ Values are the means of 12 replicates per treatment

${ }^{b} \mathrm{CON}$, control (a corn-soybean basal diet); AOS, alginate oligosaccharide (the basal diet supplemented with $100 \mathrm{mg} / \mathrm{kg}$ alginate oligosaccharide)

'BW, body weight; $A D G$, average daily body weight gain; $A D F l$, average daily feed intake; G:F, the gain-to-feed ratio

\section{Enterocyte cell cycle analysis}

For enterocyte cell cycle analysis, duodenal, jejunal and ileal epithelial cell suspensions were prepared, as described above for apoptosis detection. A total $1 \mathrm{~mL}$ of cell suspension was transferred to a $5-\mathrm{mL}$ culture tube. After adding $1 \mathrm{~mL}$ of $0.25 \%$ Triton $\mathrm{X}-100$, the mixture was incubated at $4{ }^{\circ} \mathrm{C}$ for $10 \mathrm{~min}$, and the cells washed with PBS. Next, $5 \mu \mathrm{L}$ of 7 -AAD was added to $100 \mu \mathrm{L}$ of

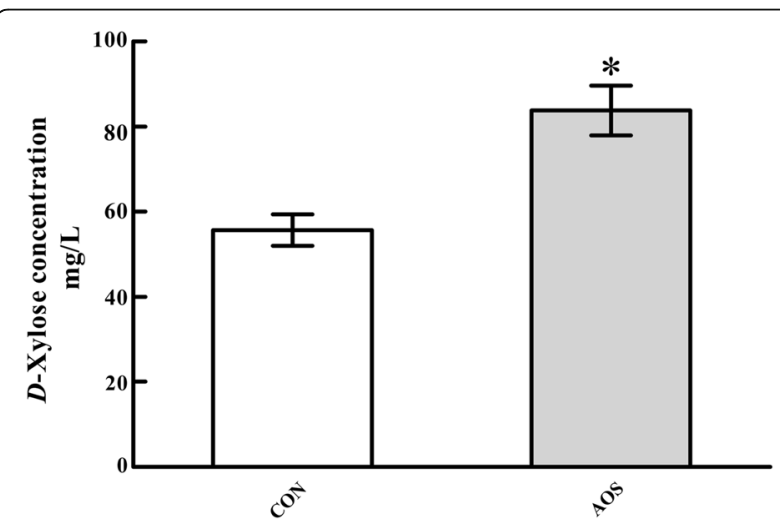

Fig. 1 Effects of alginate oligosaccharide on the serum D-xylose concentration of weaned pigs. Values are means (8 pigs/treatment), with standard errors represented by vertical bars. ${ }^{*} P<0.05$ (indicates that the serum $D$-xylose concentration is significantly higher in the AOS group than CON group). CON, control (a corn-soybean basal diet); AOS, alginate oligosaccharide (the basal diet supplemented with $100 \mathrm{mg} / \mathrm{kg}$ alginate oligosaccharide) 


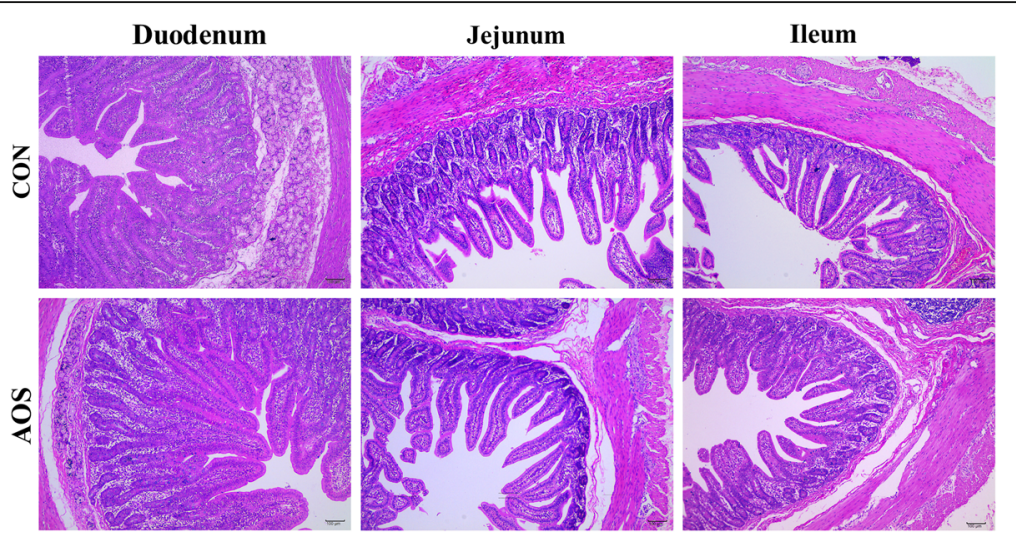

Fig. 2 Histological evaluation of the small intestinal tissues after exposure to alginate oligosaccharide $\left(H \& E_{;} \times 100\right)$. CON, control (a corn-soybean basal diet); AOS, alginate oligosaccharide (the basal diet supplemented with $100 \mathrm{mg} / \mathrm{kg}$ alginate oligosaccharide). Scale bar is $100 \mu \mathrm{m}$

cell suspension and incubated at $4{ }^{\circ} \mathrm{C}$ for $30 \mathrm{~min}$ in the dark. Finally, $400 \mu \mathrm{L}$ of PBS was added. The cell cycle distribution was assayed using a CytoFlex flow cytometer (Beckman Coulter, Inc) within 45 min and analysed by ModFit LT 5.0 (Verity Software House, Topsham, ME, USA) [28]. The proliferating index (\%) was calculated by the formula $\frac{S+\left(G_{2}+M\right)}{\left(G_{0} / G_{1}\right)+S+\left(G_{2}+M\right)} \times 100$.

\section{Total RNA isolation and reverse transcription}

Frozen duodenal, jejunal and ileal samples (about $0.1 \mathrm{~g}$ ), respectively, were pulverised in liquid nitrogen and subsequently homogenised in $1 \mathrm{~mL}$ of RNAiso Plus (Takara Biotechnology Co., Ltd., Dalian, China) to extract total RNA, according to the manufacturer's instructions. The concentration and quality of total RNA were assessed using a spectrophotometer (NanoDrop 2000, Thermo Fisher Scientific, Inc., Waltham, MA, USA), considering the high-quality absorbance ratio $(260 / 280 \mathrm{~nm})$ being within 1.8 and 2.0, and the integrity of total RNA was checked by electrophoresis on a $1 \%$ agarose gel. Next, a volume equivalent to $1 \mu \mathrm{g}$ total RNA of each duodenal, jejunal and ileal sample, respectively, was used to synthesise cDNA, based on the protocol of PrimeScript ${ }^{\text {Tw }}$ RT reagent kit with gDNA Eraser (Takara Biotechnology Co., Ltd). The synthesis was achieved in two steps: $37^{\circ} \mathrm{C}$ for $15 \mathrm{~min}$, followed by $85^{\circ} \mathrm{C}$ for $5 \mathrm{~s}$.

\section{qPCR}

Mucin 1 (MUC1), MUC2, MUC4, B-cell lymphoma-2-associated $\mathrm{X}$ protein $(B A X), \quad \mathrm{B}$-cell lymphoma-2 (BCL2), $F A S$, cysteinyl aspartate-specific proteinase-3 (caspase-3), caspase-8 and caspase-9 mRNA levels in intestinal mucosa were quantified using qPCR, as described by Wan et al. [29]. In brief, the specific primers were designed using Primer Express 3.0 software (Applied Biosystems, Foster City, CA, USA) and purchased from Sangon Biotech Co., Ltd. (Shanghai, China), as depicted in Table 2. All qPCR reactions were performed in triplicate on a QuanStudio $^{\text {Tix }} 6$ Flex Real-Time PCR System (Applied Biosystems), using SYBR $^{\bullet}$ Premix Ex Taq ${ }^{\text {Tix }}$ II (Tli RNaseH Plus) (Takara Biotechnology Co., Ltd). Amplification was performed in a final volume of $10 \mu \mathrm{L}$, which consisted of $5 \mu \mathrm{L}$ of SYBR Premix Ex Taq II (Tli RNaseH Plus, $2 \times$ ), $0.2 \mu \mathrm{L}$ ROX

Table 4 Effects of alginate oligosaccharide on the intestinal mucosal morphology of weaned pigs ${ }^{a}$

\begin{tabular}{|c|c|c|c|}
\hline \multirow[t]{2}{*}{ Item } & \multicolumn{2}{|l|}{ Treatment $^{\mathrm{b}}$} & \multirow[t]{2}{*}{$P$-value } \\
\hline & $\mathrm{CON}$ & $\mathrm{AOS}$ & \\
\hline \multicolumn{4}{|l|}{ Duodenum } \\
\hline Villus height, $\mu \mathrm{m}$ & $407.63 \pm 11.36$ & $457.88 \pm 17.07^{*}$ & 0.028 \\
\hline Villus width, $\mu \mathrm{m}$ & $132.26 \pm 5.62$ & $136.98 \pm 7.61$ & 0.626 \\
\hline Crypt depth, $\mu \mathrm{m}$ & $224.74 \pm 4.17$ & $226.91 \pm 8.58$ & 0.823 \\
\hline Villus surface area, mm² & $0.17 \pm 0.01$ & $0.20 \pm 0.01$ & 0.054 \\
\hline Villus height:Crypt depth & $1.81 \pm 0.03$ & $2.03 \pm 0.08^{*}$ & 0.030 \\
\hline \multicolumn{4}{|l|}{ Jejunum } \\
\hline Villus height, $\mu \mathrm{m}$ & $408.75 \pm 10.49$ & $456.94 \pm 12.07^{* *}$ & 0.009 \\
\hline Villus width, $\mu \mathrm{m}$ & $109.22 \pm 3.61$ & $114.36 \pm 5.18$ & 0.429 \\
\hline Crypt depth, $\mu \mathrm{m}$ & $194.80 \pm 1.95$ & $189.25 \pm 2.43$ & 0.096 \\
\hline Villus surface area, $\mathrm{mm}^{2}$ & $0.14 \pm 0.01$ & $0.16 \pm 0.01^{*}$ & 0.031 \\
\hline Villus height:Crypt depth & $2.10 \pm 0.06$ & $2.41 \pm 0.04^{* *}$ & $<0.001$ \\
\hline \multicolumn{4}{|l|}{ lleum } \\
\hline Villus height, $\mu \mathrm{m}$ & $334.83 \pm 2.86$ & $351.34 \pm 7.73$ & 0.077 \\
\hline Villus width, $\mu \mathrm{m}$ & $113.17 \pm 5.19$ & $123.39 \pm 5.07$ & 0.180 \\
\hline Crypt depth, $\mu \mathrm{m}$ & $169.61 \pm 5.19$ & $174.41 \pm 6.70$ & 0.580 \\
\hline Villus surface area, mm² & $0.12 \pm 0.01$ & $0.14 \pm 0.01$ & 0.120 \\
\hline Villus height:Crypt depth & $2.01 \pm 0.05$ & $2.04 \pm 0.09$ & 0.793 \\
\hline
\end{tabular}

${ }^{*} P<0.05$ versus the CON group. ${ }^{* *} P<0.01$ versus the $\mathrm{CON}$ group ${ }^{a}$ Values are the means of 8 replicates per treatment

${ }^{b} \mathrm{CON}$, control (a corn-soybean basal diet); AOS, alginate oligosaccharide (the basal diet supplemented with $100 \mathrm{mg} / \mathrm{kg}$ alginate oligosaccharide) 
Table 5 Effects of alginate oligosaccharide on the intestinal goblet and columnar cell counts of weaned pigs ${ }^{a}$

\begin{tabular}{|c|c|c|c|}
\hline \multirow[t]{2}{*}{ Item } & \multicolumn{2}{|l|}{ Treatment $^{\mathrm{b}}$} & \multirow[t]{2}{*}{$P$-value } \\
\hline & CON & AOS & \\
\hline \multicolumn{4}{|c|}{ Duodenum (number/villus) } \\
\hline Goblet cells & $8.69 \pm 0.26$ & $10.03 \pm 0.43^{*}$ & 0.018 \\
\hline Columnar cells & $71.94 \pm 3.10$ & $75.09 \pm 3.53$ & 0.514 \\
\hline \multicolumn{4}{|c|}{ Jejunum (number/villus) } \\
\hline Goblet cells & $7.31 \pm 0.34$ & $9.79 \pm 0.23^{* *}$ & $<0.001$ \\
\hline Columnar cells & $70.25 \pm 1.57$ & $73.55 \pm 1.51$ & 0.153 \\
\hline \multicolumn{4}{|c|}{ Ileum (number/villus) } \\
\hline Goblet cells & $11.33 \pm 0.79$ & $11.60 \pm 0.37$ & 0.758 \\
\hline Columnar cells & $78.20 \pm 1.77$ & $81.91 \pm 2.40$ & 0.233 \\
\hline
\end{tabular}

${ }^{*} P<0.05$ versus the CON group. ${ }^{* *} P<0.01$ versus the CON group ${ }^{a}$ Values are the means of 8 replicates per treatment

${ }^{b} \mathrm{CON}$, control (a corn-soybean basal diet); AOS, alginate oligosaccharide (the basal diet supplemented with $100 \mathrm{mg} / \mathrm{kg}$ alginate oligosaccharide)

Reference Dye II (50×), $0.4 \mu \mathrm{L}$ forward primer $(10 \mu \mathrm{mol} /$ $\mathrm{L}), 0.4 \mu \mathrm{L}$ reverse primer $(10 \mu \mathrm{mol} / \mathrm{L}), 1 \mu \mathrm{L} \mathrm{cDNA}$ and $3 \mu \mathrm{L}$ diethylpyrocarbonate-treated water, under the following cycling conditions: $95{ }^{\circ} \mathrm{C}$ for $30 \mathrm{~s}$, followed by 40 cycles: at $95{ }^{\circ} \mathrm{C}$ for $5 \mathrm{~s}$ and $60{ }^{\circ} \mathrm{C}$ for $34 \mathrm{~s}$. After the amplification phase, a melt curve analysis was performed at $95{ }^{\circ} \mathrm{C}$ for $15 \mathrm{~s}, 60{ }^{\circ} \mathrm{C}$ for $1 \mathrm{~min}$ and $95{ }^{\circ} \mathrm{C}$ for $15 \mathrm{~s}$, to confirm the specificity of the amplification reaction. Porcine glyceraldehyde-3-phosphate dehydrogenase $(G A P D H)$ gene was chosen as the housekeeping gene, to normalise the expression levels of the target genes. Amplification efficiencies were calculated from the specific gene standard curves that were generated from 10-fold serial dilutions, quantifying six concentrations. After verification that the primers amplified with an efficiency of approximately $100 \%$, the relative gene expressions between the two groups were calculated, based on the $2^{-\Delta \Delta C t}$ method [30].

\section{Statistical analysis}

All data were analysed by a Student's $t$-test using SAS 9.0 (SAS Inst., Inc., Cary, NC, USA). Each pig served as a statistical unit. Data are shown as the mean \pm standard error. $P<0.05$ was considered significant when used to compare the differences between the $\mathrm{CON}$ group and the AOS group.

\section{Results}

\section{Growth performance}

Although AOS addition did not have a significant effect $(P>0.05)$ on G:F, the ADG and ADFI were elevated $(P<$ $0.05)$ by supplemental AOS throughout the entire experimental period (Table 3).

\section{Serum $D$-xylose concentration}

Fig. 1 reveals the effects of AOS supplementation on the serum $D$-xylose level in weaned pigs. The data showed that the pigs in the AOS group had a higher $(P<0.05)$ serum $D$-xylose concentration compared to the CON group.

\section{Intestinal architecture}

$H \& E$ staining of the small intestine tissues after exposure to AOS indicated that AOS supplementation caused duodenal and jejunal architecture alternations but failed to change the ileal structure (Fig. 2).

Next, the specific duodenal, jejunal and ileal morphological parameters for the two groups were calculated (Table 4). Dietary AOS inclusion resulted in a significant

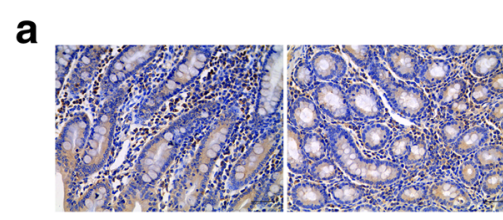

\section{b}
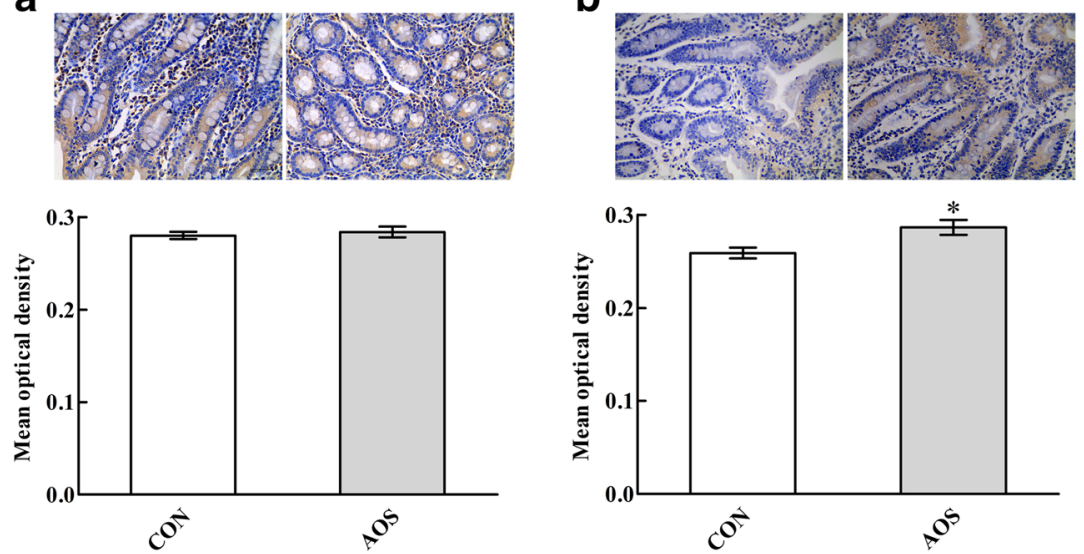

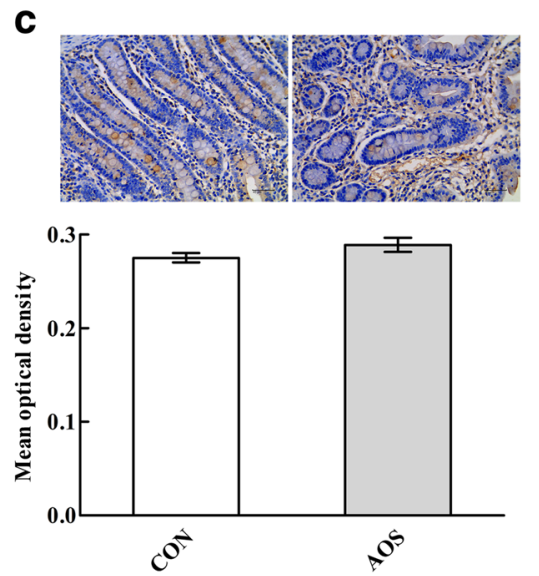

Fig. 3 Effects of alginate oligosaccharide on the slgA content in the duodenum (a), jejunum (b) and ileum (c) of weaned pigs (immunohistochemistry; $\times 400$ ). Values are means (8 pigs/treatment), with standard errors represented by vertical bars. ${ }^{*} P<0.05$ (indicates that the slgA content is significantly higher in the AOS group than CON group). CON, control (a corn-soybean basal diet); AOS, alginate oligosaccharide (the basal diet supplemented with $100 \mathrm{mg} / \mathrm{kg}$ alginate oligosaccharide). slgA, secretory immunoglobulin A. Scale bar is $40 \mu \mathrm{m}$ 


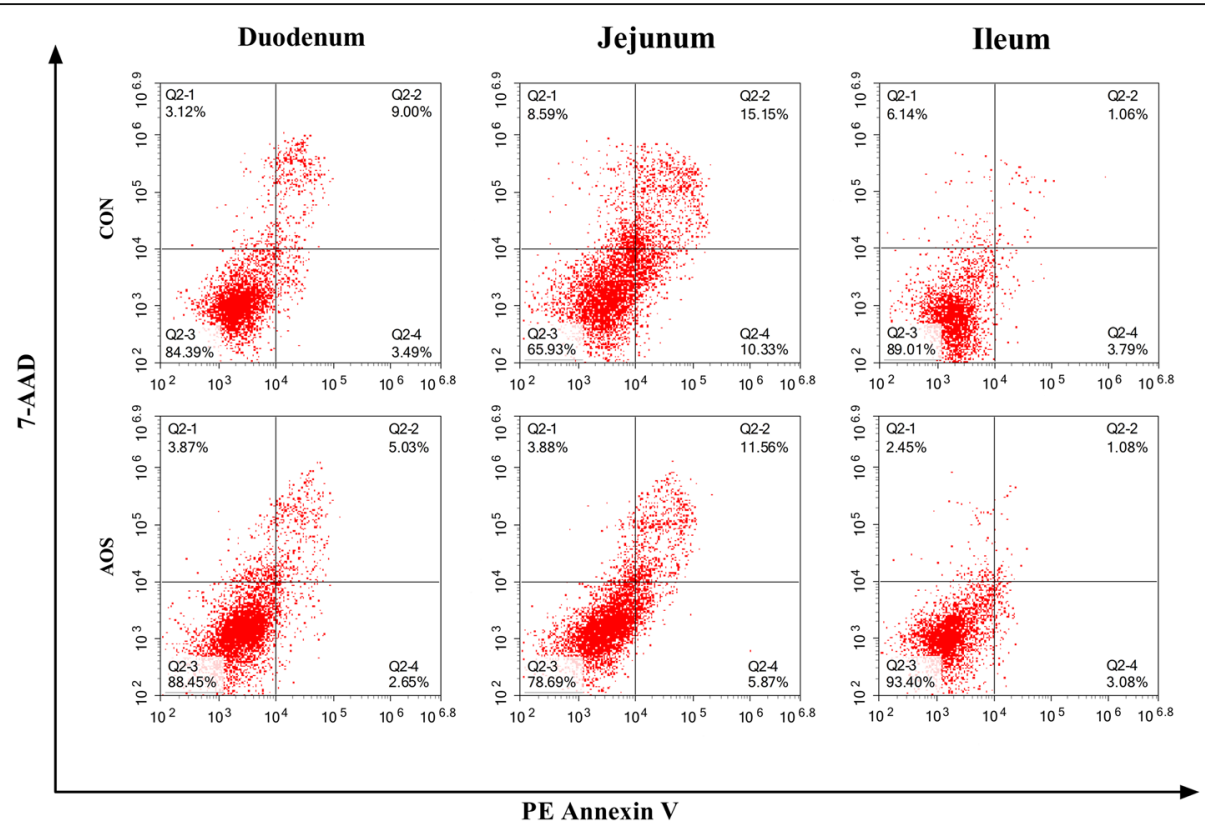

Fig. 4 Percentage of apoptotic cells in the small intestine of weaned pigs fed diets containing or lacking alginate oligosaccharide. Frames were divided into four quadrants: Q2-1 represents necrotic cells; Q2-2 represents late-stage apoptotic cells; Q2-3 represents normal cells; Q2-4 represents early-stage apoptotic cells. CON, control (a corn-soybean basal diet); AOS, alginate oligosaccharide (the basal diet supplemented with $100 \mathrm{mg} / \mathrm{kg}$ alginate oligosaccharide). 7-AAD, 7-aminoactinomycin D

increase $(P<0.05)$ in the villus height and the villus height-to-crypt depth ratio in both, the duodenum and jejunum, as well as the jejunal villus surface area. Moreover, there were no significant differences $(P>0.05)$ in the ileal morphological parameters between the two treatments.

\section{Goblet and columnar cell counts}

A summary of the goblet and columnar cell counts after AOS supplementation is provided in Table 5. AOS supplementation did not affect $(P>0.05)$ the columnar cell counts but increased $(P<0.05)$ the goblet cell counts in the duodenum and jejunum. There was no impact $(P>$ 0.05 ) on the ileal goblet and columnar cell counts by AOS ingestion.

\section{slgA content}

Fig. 3 presents the mean optical density of intestinal sIgA in the CON and AOS groups. Interestingly, the jejunal mean optical density of sIgA was higher $(P<0.05)$ in the AOS group than CON group, whereas the duodenal and ileal mean optical densities of sIgA were not affected $(P>0.05)$ by AOS supplementation.

\section{Apoptotic percentage}

The impacts of AOS on the intestinal epithelial cell apoptosis are demonstrated in Fig. 4 and Table 6. Compared to the control group, AOS supplementation decreased $(P<0.05)$ the early- and late-stage apoptotic cell percentages, as well as the total apoptotic cells percentage, in the jejunal epithelium. Furthermore, there were no marked differences $(P>0.05)$ in the duodenal and ileal epithelial cell apoptotic percentages between the AOS and CON groups.

\section{Cell cycle distribution}

Fig. 5 and Table 7 demonstrate that AOS supplementation decreased $(P<0.05)$ the proportion of $G_{0} / G_{1}$ phase

Table 6 Effects of alginate oligosaccharide on the enterocyte apoptosis of weaned pigs ${ }^{a}$

\begin{tabular}{llll}
\hline Item & \multicolumn{2}{l}{ Treatment $^{\mathrm{b}}$} & \multirow{2}{*}{ P-value } \\
\cline { 2 - 3 } & CON & AOS & \\
\hline Duodenum, \% & & 0.909 \\
Early-stage apoptotic cells & $2.94 \pm 0.31$ & $2.98 \pm 0.22$ & 0.055 \\
Late-stage apoptotic cells & $9.31 \pm 1.18$ & $5.92 \pm 0.46$ & 0.083 \\
Total apoptotic cells & $12.25 \pm 1.32$ & $8.90 \pm 0.61$ & \\
Jejunum, \% & & & 0.018 \\
Early-stage apoptotic cells & $10.98 \pm 0.99$ & $6.31 \pm 0.68^{*}$ & 0.022 \\
Late-stage apoptotic cells & $15.70 \pm 0.85$ & $10.86 \pm 1.02^{*}$ & $<0.001$ \\
Total apoptotic cells & $26.68 \pm 0.61$ & $17.17 \pm 0.35^{* *}$ & \\
lleum, \% & & & 0.149 \\
Early-stage apoptotic cells & $3.83 \pm 0.46$ & $2.93 \pm 0.34$ & 0.618 \\
Late-stage apoptotic cells & $1.14 \pm 0.18$ & $1.03 \pm 0.11$ & 0.093 \\
Total apoptotic cells & $4.97 \pm 0.42$ & $3.96 \pm 0.32$ &
\end{tabular}

${ }^{*} P<0.05$ versus the CON group. ${ }^{* *} P<0.01$ versus the CON group

${ }^{a} V$ alues are the means of 8 replicates per treatment

${ }^{\mathrm{b}} \mathrm{CON}$, control (a corn-soybean basal diet); AOS, alginate oligosaccharide (the basal diet supplemented with $100 \mathrm{mg} / \mathrm{kg}$ alginate oligosaccharide) 
cells but increased $(P<0.05)$ the ratio of $S$ phase cells, as well as the proliferating index, in the jejunal epithelium. Furthermore, the duodenal and ileal cell cycle distributions did not markedly change $(P>0.05)$ after AOS supplementation.

\section{Mucins gene expressions}

According to Fig. 6, pigs supplemented with AOS had an increase $(P<0.05)$ in mucin $2(M U C 2)$ transcription in the duodenal and ileal mucosae, but not $(P>0.05)$ in the ileal mucosa. Besides, no effects $(P>0.05)$ were detected on the MUC1 and MUC4 transcriptions in all of the three intestinal mucosae after AOS ingestion.

\section{Apoptosis-related genes expression}

The transcriptional levels of apoptosis-related genes in the small intestine are illustrated in Fig. 7. Compared to the CON group, AOS ingestion decreased $(P<0.05)$ the pro-apoptotic factor $B A X$, caspase- 3 and caspase- 9 mRNA abundances and increased $(P<0.05)$ the anti-apoptotic factor $B C L 2$ mRNA abundance in the jejunal mucosa, but not $(P>0.05)$ in the duodenal and ileal mucosa. However, no difference $(P>0.05)$ was observed in the FAS and caspase- 8 mRNA abundances among the three intestinal mucosae, after AOS supplementation.

\section{Discussion}

Compromising alterations in intestinal architecture, such as villus atrophy and crypt hyperplasia, are commonly encountered in post-weaning piglets [31, 32]. However, a decrease in the villus height-to-crypt depth ratio or a reduced villus surface area is considered deleterious for digestion and absorption and could lead to retarded growth in post-weaning piglets [33, 34]. Consequently, maintaining the normal intestinal architecture and function is essential for growth and development in piglets after weaning [35]. It is therefore noteworthy that an increased villus height-to-crypt depth ratio in the duodenum and jejunum, as well as an increased villus surface area in the jejunum, was seen in AOS-supplemented pigs. These observations support the notion that AOS inclusion in the diet can change the intestinal morphological structure, and thereby promote the intestinal digestion-absorption function in piglets after weaning [36]. Meanwhile, the increased entry of orally administered $D$-xylose into the blood after AOS ingestion further corroborates the aforementioned view [37]. These findings are sufficient to suggest that the growth-promoting effects of AOS on weaned pigs can be partially attributable to the improved intestinal morphology and function.

There is plentiful of evidence that the early weaning process is correlated with impaired intestinal barrier function in piglets [38, 39]. Interestingly, dietary

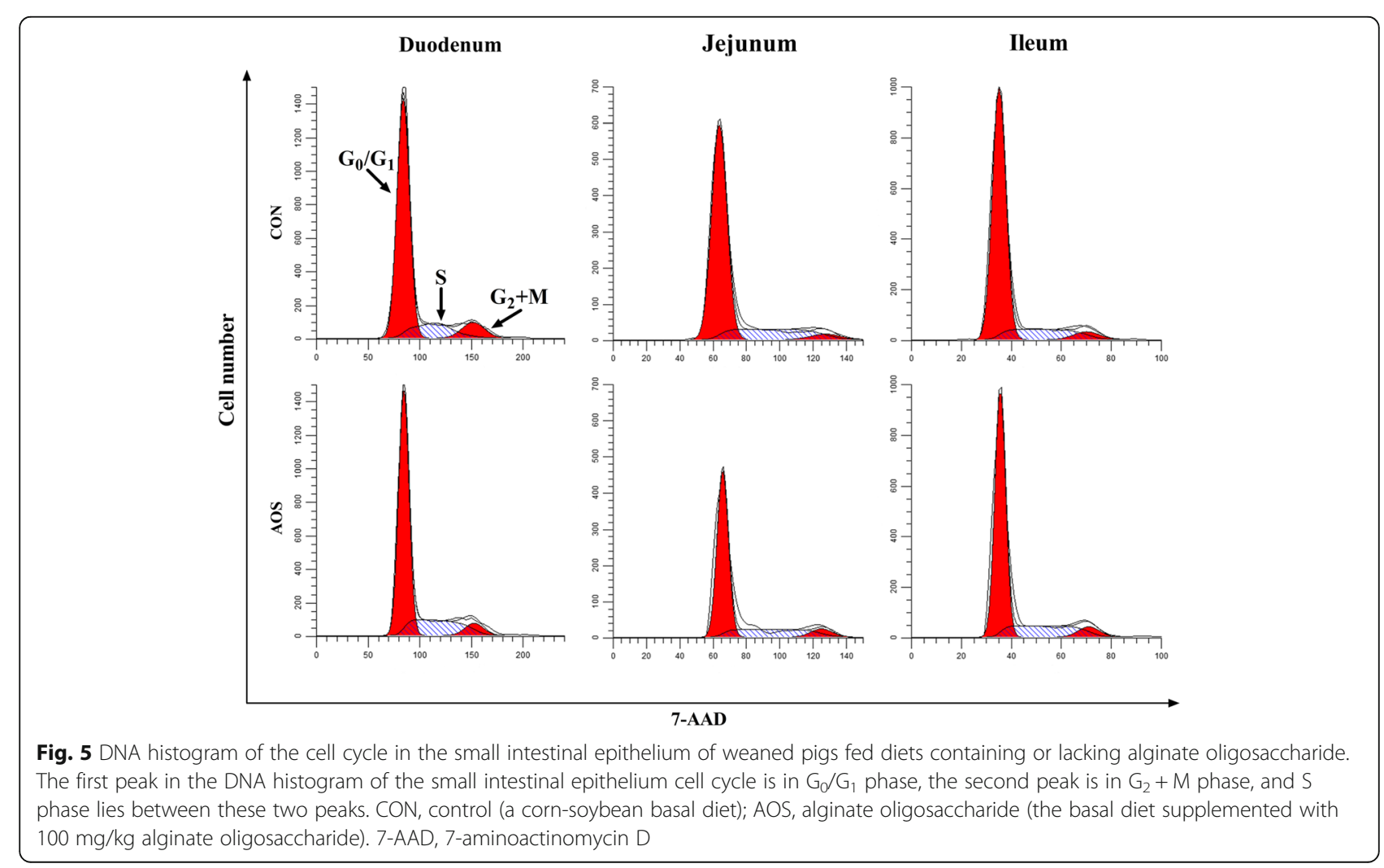


Table 7 Effects of alginate oligosaccharide on the enterocyte proliferation of weaned pigs ${ }^{\mathrm{a}}$

\begin{tabular}{|c|c|c|c|}
\hline \multirow[t]{2}{*}{ Item } & \multicolumn{2}{|l|}{ Treatment $^{\mathrm{b}}$} & \multirow[t]{2}{*}{$P$-value } \\
\hline & $\mathrm{CON}$ & AOS & \\
\hline \multicolumn{4}{|l|}{ Duodenum, \% } \\
\hline $\mathrm{G}_{0} / \mathrm{G}_{1}$ phase cells & $75.15 \pm 1.41$ & $70.65 \pm 1.37$ & 0.051 \\
\hline S phase cells & $18.71 \pm 1.25$ & $22.05 \pm 0.78$ & 0.053 \\
\hline $\mathrm{G}_{2}+\mathrm{M}$ phase cells & $6.02 \pm 1.05$ & $6.54 \pm 0.72$ & 0.698 \\
\hline Proliferating index & $24.77 \pm 1.39$ & $28.81 \pm 1.28$ & 0.064 \\
\hline \multicolumn{4}{|l|}{ Jejunum, \% } \\
\hline $\mathrm{G}_{0} / \mathrm{G}_{1}$ phase cells & $75.93 \pm 1.81$ & $70.42 \pm 0.78^{*}$ & 0.023 \\
\hline S phase cells & $16.66 \pm 1.37$ & $21.88 \pm 0.87^{*}$ & 0.012 \\
\hline $\mathrm{G}_{2}+\mathrm{M}$ phase cells & $5.98 \pm 0.74$ & $7.62 \pm 0.55$ & 0.112 \\
\hline Proliferating index & $22.99 \pm 1.51$ & $29.53 \pm 0.79^{* *}$ & 0.005 \\
\hline \multicolumn{4}{|l|}{ Ileum, \% } \\
\hline$G_{0} / G_{1}$ phase cells & $73.57 \pm 2.04$ & $68.74 \pm 1.98$ & 0.128 \\
\hline S phase cells & $17.78 \pm 0.90$ & $21.64 \pm 1.43$ & 0.052 \\
\hline $\mathrm{G}_{2}+\mathrm{M}$ phase cells & $8.10 \pm 1.05$ & $9.13 \pm 1.11$ & 0.521 \\
\hline Proliferating index & $26.04 \pm 1.90$ & $30.89 \pm 2.27$ & 0.140 \\
\hline
\end{tabular}

${ }^{*} P<0.05$ versus the CON group. ${ }^{* *} P<0.01$ versus the $\mathrm{CON}$ group

${ }^{a}$ Values are the means of 8 replicates per treatment

${ }^{b} \mathrm{CON}$, control (a corn-soybean basal diet); AOS, alginate oligosaccharide (the

basal diet supplemented with $100 \mathrm{mg} / \mathrm{kg}$ alginate oligosaccharide)

supplementation with some oligosaccharides provides a promising approach to improve the intestinal barrier function in weaned pigs [40,41]. Therefore, we expected that AOS would have benefits on intestinal barrier function when administered to weaned pigs. In the present study, AOS supplementation increased the jejunal mucosal sIgA content, suggesting that dietary inclusion of AOS could enhance the intestinal immune barrier function in weaned pigs $[42,43]$. Goblet cells are specialised cells found along the crypt-villus axis of the small intestine that biosynthesis, assemble and secrete mucins (including MUC1, MUC2 and MUC4), which contribute to the mucus layer in the intestine, providing an intestinal chemical barrier function [44-46]. In the current study, more goblet cells in the duodenum and jejunum were noticed after AOS addition, accompanied by an up-regulated $M U C 2$ transcriptional level in the duodenum and jejunum, indicating that AOS supplementation also improved the intestinal chemical barrier function in weaned pigs. Together, these results revealed that AOS is conducive for repairing weaning-associated intestinal barrier dysfunction in piglets and then possibly improved growth performance.

Apoptosis is a form of physiological cell death, important in controlling the epithelial turnover in the intestinal mucosa. However, dysregulated or excessive apoptosis results in severe intestinal pathology [47]. A recent research certified that weaning could increase enterocyte apoptosis in piglets [48]. Here, we noted that apoptosis was less prevalent in the jejunal epithelial cells in the AOS group than control group, suggesting that AOS may have a protective influence against enterocyte apoptosis promoted by weaning of piglets. In addition to inducing enterocyte apoptosis, weaning also inhibits intestinal epithelial cell proliferation in piglets [49]. Here, we identified that AOS supplementation increased jejunal epithelial cell proliferation, through promoting the transition from $G_{0} / G_{1}$ to $S$ phase of the cell cycle. As such, it was confirmed that AOS could alleviate the elevated apoptosis and depressed proliferation of intestinal epithelial cells in piglets caused by weaning and consequently mitigate weaning-induced intestinal structural injury. So far, the molecular mechanisms by which AOS inhibits enterocyte apoptosis in weaned pigs remain unclear. Therefore, we studied the effects of AOS addition in the diet, on signalling molecules involved in enterocyte apoptosis in weaned pigs.

It is well-known that the intrinsic (mitochondrial pathway) and extrinsic (cytoplasmic pathway) pathways are two major apoptotic routes [50]. The intrinsic pathway
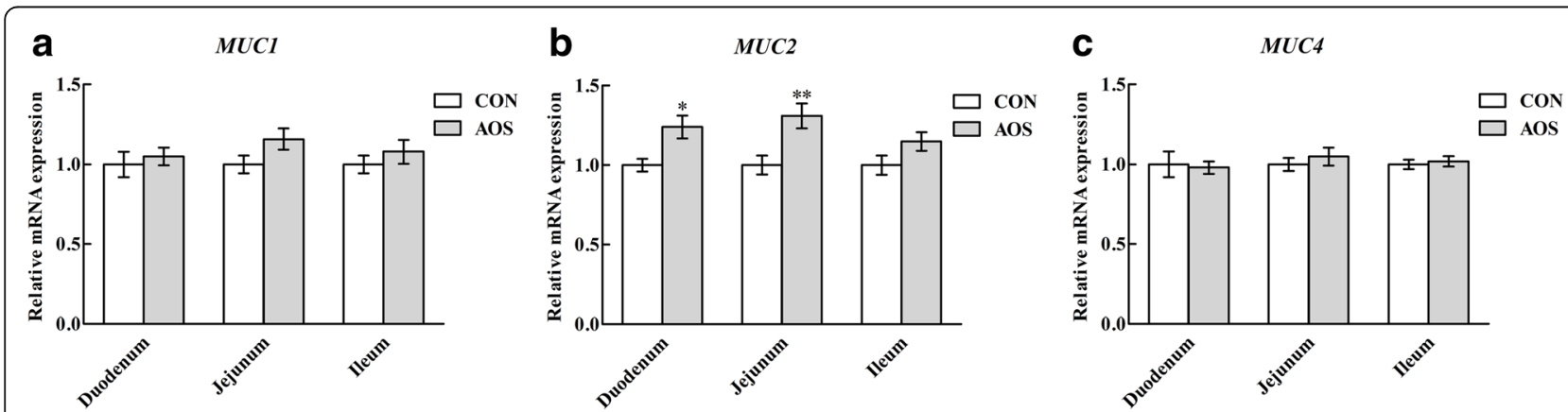

Fig. 6 Relative mRNA abundances of $M U C 1(\mathbf{a}), M U C 2(\mathbf{b})$ and MUC4 (c) in the small intestine of weaned pigs fed diets containing or lacking alginate oligosaccharide. Values are means (8 pigs/treatment), with standard errors represented by vertical bars. ${ }^{*} P<0.05$ or ${ }^{* *} P<0.01$ (indicates that the gene mRNA levels between the AOS and CON groups differ significantly). CON, control (a corn-soybean basal diet); AOS, alginate oligosaccharide (the basal diet supplemented with $100 \mathrm{mg} / \mathrm{kg}$ alginate oligosaccharide). MUC1, mucin 1; MUC2, mucin 2; MUC4, mucin 4 


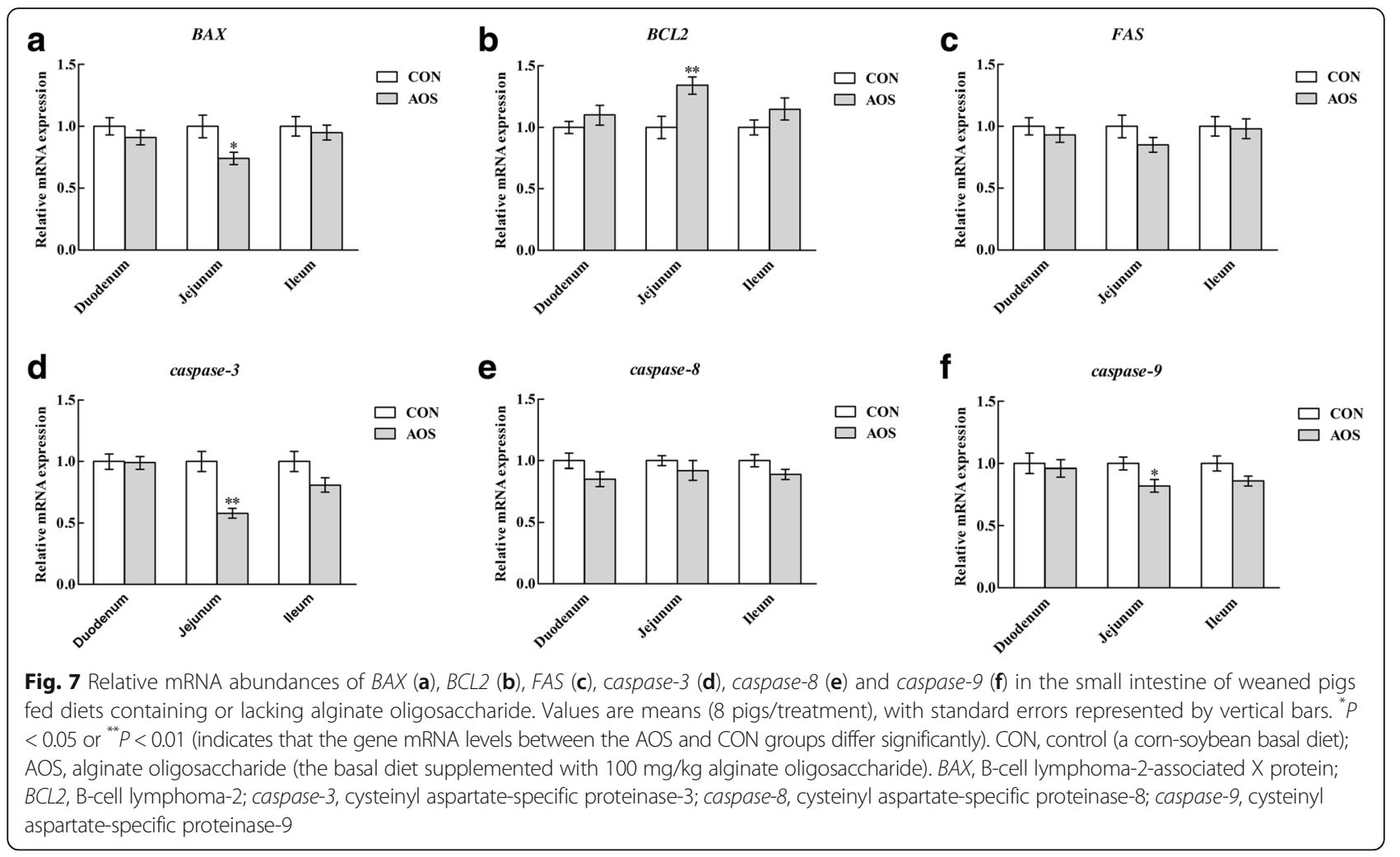

is mitochondria-mediated and mainly regulated by the BCL2 family [51, 52], whereas the extrinsic pathway is triggered through the Fas death receptor, a member of the tumour necrosis factor receptor superfamily [53]. Both pathways converge to a final common path involving the activation of a cascade of proteases called caspases that cleave regulatory and structural molecules, culminating in the death of the cell $[54,55]$. To illustrate the mechanisms underlying the suppression effects of AOS on weaning-induced intestinal epithelial cell apoptosis in piglets, the apoptosis-related gene transcriptional levels, including $B A X, B C L 2, F A S$, caspase-3, caspase-8 and caspase-9, were determined. The present study evidenced that AOS ingestion decreased the pro-apoptotic factor BAX, caspase-3 and caspase-9 mRNA abundances and increased the anti-apoptotic factor $B C L 2$ mRNA abundance in the jejunum. Thus, AOS inhibition of intestinal epithelial cell death in weaned pigs might be inclined to decrease mitochondria-dependent apoptosis. Our findings explained the positive role of AOS in rendering the intestinal epithelial cells resistant to weaning-induced apoptosis in piglets.

\section{Conclusions}

To summarise, we indicated that supplementing the diet with $100 \mathrm{mg} / \mathrm{kg}$ AOS improved both the intestinal morphology and barrier function and inhibited the enterocyte death by reducing mitochondria-dependent apoptosis in weaned pigs. Furthermore, these changes were accompanied by an enhanced growth performance in weaned pigs. Our observations provide a strong scientific basis for AOS as an alternative to the use of antibiotic growth promoters in swine production and also imply AOS has potential application in clinical nutrition to prevent intestinal disruptions.

\section{Abbreviations}

7-AAD: 7-aminoactinomycin D; ADFI: Average daily feed intake;

ADG: Average daily body weight gain; AOS: Alginate oligosaccharide (the basal diet supplemented with $100 \mathrm{mg} / \mathrm{kg}$ alginate oligosaccharide); BAX: Bcell lymphoma-2-associated X protein; BCL2: B-cell lymphoma-2; BW: Body weight; CON: Control (a corn-soybean basal diet); caspase-3: Cysteinyl aspartate-specific proteinase-3; caspase-8: Cysteinyl aspartate-specific proteinase-8; caspase-9: Cysteinyl aspartate-specific proteinase-9; DAB: 3,3'diaminobenzidine; G: a-L-guluronic acid; GAPDH: glyceraldehyde-3phosphate dehydrogenase; G:F: The gain-to-feed ratio; M: $\beta$-D-mannuronic acid; MUC1: Mucin 1; MUC2: Mucin 2; MUC4: Mucin 4; PBS: phosphate buffered saline; qPCR: quantitative real-time polymerase chain reaction; slgA: Secretory immunoglobulin A

\section{Acknowledgements}

We thank Anran Jiao, Fei Jiang and Huifen Wang for their diligent contribution to the animal experiments. We also express our gratitude to Zhengqiang Yu for his excellent technical assistance in enterocyte apoptosis and cell cycle detection by flow cytometry.

\section{Funding}

This work was supported by the Special Fund for Agro-scientific Research in the Public Interest (201403047).

\section{Availability of data and materials}

All data generated or analysed during this study are available from the corresponding author on reasonable request. 


\section{Authors' contributions}

Jun He designed and supervised the experiments. Jin Wan and Jiao Zhang carried out the experiments and performed statistical data analysis. Daiwen Chen, Bing Yu, Xiangbing Mao, Ping Zheng, Jie Yu and Junqiu Luo gave tremendous help in conducting experiments. Jin Wan was also in charge of preparing the manuscript. All authors have read and approved the final manuscript.

\section{Ethics approva}

All procedures in the present study involving animals were approved by the Animal Care and Use Committee of Sichuan Agricultural University (Chengdu, China).

\section{Competing interests}

The authors declare that they have no competing interests.

\section{Received: 21 January 2018 Accepted: 6 June 2018} Published online: 16 August 2018

\section{References}

1. Kim JC, Hansen CF, Mullan BP, Pluske JR. Nutrition and pathology of weaner pigs: nutritional strategies to support barrier function in the gastrointestinal tract. Anim Feed Sci Technol. 2012:173:3-16.

2. Smith F, Clark JE, Overman BL, Tozel CC, Huang JH, Rivier JE, et al. Early weaning stress impairs development of mucosal barrier function in the porcine intestine. Am J Physiol Gastrointest Liver Physiol. 2010;298:G352-G63.

3. Boudry G, Péron V, Le Huërou-Luron I, Lallès JP, Sève B. Weaning induces both transient and long-lasting modifications of absorptive, secretory, and barrier properties of piglet intestine. J Nutr. 2004;134:2256-62.

4. $\mathrm{Hu} C \mathrm{CH}$, Song ZH, Xiao K, Song J, Jiao LF, Ke YL. Zinc oxide influences intestinal integrity, the expressions of genes associated with inflammation and TLR4-myeloid differentiation factor 88 signaling pathways in weanling pigs. Innate Immun. 2014;20:478-86.

5. Yin J, Wu MM, Xiao H, Ren WK, Duan JL, Yang G, et al. Development of an antioxidant system after early weaning in piglets. J Anim Sci. 2014;92:612-9.

6. Zhu LH, Zhao KL, Chen XL, Xu JX. Impact of weaning and an antioxidant blend on intestinal barrier function and antioxidant status in pigs. J Anim Sci. 2012;90:2581-9.

7. Yang HS, Xiong X, Wang XC, Li TJ, Yin YL. Effects of weaning on intestinal crypt epithelial cells in piglets. Sci Rep. 2016;6:36939.

8. Wan J, Li Y, Chen DW, Yu B, Zheng P, Mao XB, et al. Expression of a tandemly arrayed plectasin gene from Pseudoplectania nigrella in Pichia pastoris and its antimicrobial activity. J Microbiol Biotechnol. 2016;26:461-8.

9. Yin XX, Song FJ, Gong YH, Tu XC, Wang YX, Cao SY, et al. A systematic review of antibiotic utilization in China. J Antimicrob Chemother. 2013;68:2445-52.

10. Gill EE, Franco OL, Hancock REW. Antibiotic adjuvants: diverse strategies for controlling drug-resistant pathogens. Chem Biol Drug Des. 2015;85:56-78.

11. Liu P, Piao XS, Kim SW, Wang L, Shen YB, Lee HS, et al. Effects of chitooligosaccharide supplementation on the growth performance, nutrient digestibility, intestinal morphology, and fecal shedding of and in weaning pigs. J Anim Sci. 2008;86:2609-18.

12. Wu Y, Pan L, Shang QH, Ma XK, Long SF, Xu YT, et al. Effects of isomaltooligosaccharides as potential prebiotics on performance, immune function and gut microbiota in weaned pigs. Anim Feed Sci Technol. 2017;230:126-35.

13. Ruvinov E, Cohen S. Alginate biomaterial for the treatment of myocardial infarction: progress, translational strategies, and clinical outlook: from ocean algae to patient bedside. Adv Drug Deliver Rev. 2016;96:54-76.

14. Lu JJ, Yang $\mathrm{H}$, Hao J, Wu CL, Liu L, Xu NY, et al. Impact of hydrolysis conditions on the detection of mannuronic to guluronic acid ratio in alginate and its derivatives. Carbohydr Polym. 2015;122:180-8.

15. Guo JJ, Ma LL, Shi HT, Zhu JB, Wu J, Ding ZW, et al. Alginate oligosaccharide prevents acute doxorubicin cardiotoxicity by suppressing oxidative stress and endoplasmic reticulum-mediated apoptosis. Mar Drugs. 2016;14:231.

16. Wang $P$, Jiang $X \mathrm{~L}$, Jiang $Y \mathrm{H}, \mathrm{Hu} X \mathrm{XK}$, Mou HJ, Li M, et al. In vitro antioxidative activities of three marine oligosaccharides. Nat Prod Res. 2007:21:646-54.

17. Tusi SK, Khalaj L, Ashabi G, Kiaei M, Khodagholi F. Alginate oligosaccharide protects against endoplasmic reticulum- and mitochondrial-mediated apoptotic cell death and oxidative stress. Biomaterials. 2011;32:5438-58.

18. Zhou R, Shi XY, Gao Y, Cai N, Jiang ZD, Xu X. Anti-inflammatory activity of guluronate oligosaccharides obtained by oxidative degradation from alginate in lipopolysaccharide-activated murine macrophage RAW 264.7 cells. J Agric Food Chem. 2015:63:160-8.

19. Yang Y, Ma ZH, Yang GK, Wan J, Li GJ, Du LJ, et al. Alginate oligosaccharide indirectly affects toll-like receptor signaling via the inhibition of microrna$29 \mathrm{~b}$ in aneurysm patients after endovascular aortic repair. Drug Des Devel Ther. 2017;11:2565-79.

20. Wan J, Zhang J, Chen DW, Yu B, He J. Effects of alginate oligosaccharide on the growth performance, antioxidant capacity and intestinal digestion-absorption function in weaned pigs. Anim Feed Sci Technol. 2017;234:118-27.

21. National Research Council. Nutrient requirements of swine. 11th ed. Washington, DC: National Academics Press; 2012.

22. Hou YQ, Wang L, Zhang W, Yang ZG, Ding BY, Zhu HL, et al. Protective effects of $\mathrm{N}$-acetylcysteine on intestinal functions of piglets challenged with lipopolysaccharide. Amino Acids. 2012;43:1233-42.

23. Wan J, Li Y, Chen DW, Yu B, Chen G, Zheng P, et al. Recombinant plectasin elicits similar improvements in the performance and intestinal mucosa growth and activity in weaned pigs as an antibiotic. Anim Feed Sci Technol. 2016;211:216-26.

24. Chen H, Mao XB, He J, Yu B, Huang ZQ, Yu J, et al. Dietary fibre affects intestinal mucosal barrier function and regulates intestinal bacteria in weaning piglets. Br J Nutr. 2013;110:1837-48.

25. Fang TT, Liu GM, Cao W, Wu XJ, Jia G, Zhao H, et al. Spermine: new insights into the intestinal development and serum antioxidant status of suckling piglets. RSC Adv. 2016;6:31323-35.

26. Cao W, Liu GM, Fang TT, Wu XJ, Jia G, Zhao H, et al. Effects of spermine on the morphology, digestive enzyme activities, and antioxidant status of jejunum in suckling rats. RSC Adv. 2015;5:76607-14.

27. Yu ZQ, Wang FY, Liang N, Wang $C H$, Peng $X$, Fang J, et al. Effect of selenium supplementation on apoptosis and cell cycle blockage of renal cells in broilers fed a diet containing aflatoxin B1. Biol Trace Elem Res. 2015; 168:242-51

28. Haag D, Goerttler K, Tschahargane C. The proliferative index (PI) of human breast cancer as obtained by flow cytometry. Pathology-Research and Practice. 1984;178:315-22.

29. Wan J, Jiang F, Zhang J, Xu QS, Chen DW, Yu B, et al. Amniotic fluid metabolomics and biochemistry analysis provides novel insights into the diet-regulated foetal growth in a pig model. Sci Rep. 2017;7:44782.

30. Livak KJ, Schmittgen TD. Analysis of relative gene expression data using real-time quantitative $P C R$ and the $2^{-\Delta \Delta C t}$ method. Methods. 2001;25: 402-8.

31. Montagne L, Boudry G, Favier C, Le Huërou-Luron I, Lallès JP, Sève B. Main intestinal markers associated with the changes in gut architecture and function in piglets after weaning. Br J Nutr. 2007:97:45-57.

32. $\mathrm{Hu} \mathrm{CH}$, Xiao K, Luan ZS, Song J. Early weaning increases intestinal permeability, alters expression of cytokine and tight junction proteins, and activates mitogen-activated protein kinases in pigs. J Anim Sci. 2013;91: 1094-101.

33. Montagne L, Pluske JR, Hampson DJ. A review of interactions between dietary fibre and the intestinal mucosa, and their consequences on digestive health in young non-ruminant animals. Anim Feed Sci Technol. 2003;108:95-117.

34. Wijtten PJ, van der Meulen J, Verstegen MW. Intestinal barrier function and absorption in pigs after weaning: a review. Br J Nutr. 2011:105:967-81.

35. Pluske JR, Hampson DJ, Williams $\mathbb{H}$. Factors influencing the structure and function of the small intestine in the weaned pig: a review. Livest Prod Sci. 1997:51:215-36

36. Wan J, Jiang F, Xu QS, Chen DW, He J. Alginic acid oligosaccharide accelerates weaned pig growth through regulating antioxidant capacity, immunity and intestinal development. RSC Adv. 2016;6:87026-35.

37. Hou YQ, Wang L, Ding BY, Liu YL, Zhu HL, Liu J, et al. Dietary aketoglutarate supplementation ameliorates intestinal injury in lipopolysaccharide-challenged piglets. Amino Acids. 2010;39:555-64.

38. Moeser AJ, Ryan KA, Nighot PK, Blikslager AT. Gastrointestinal dysfunction induced by early weaning is attenuated by delayed weaning and mast cell blockade in pigs. Am J Physiol Gastrointest Liver Physiol. 2007;293:G413-G1.

39. McLamb BL, Gibson AJ, Overman EL, Stahl C, Moeser AJ. Early weaning stress in pigs impairs innate mucosal immune responses to enterotoxigenic E coli challenge and exacerbates intestinal injury and clinical disease. PLoS One. 2013;8:e59838.

40. Wan J, Jiang F, Xu OS, Chen DW, Yu B, Huang ZQ et al. New insights into the role of chitosan oligosaccharide in enhancing growth performance, 
antioxidant capacity, immunity and intestinal development of weaned pigs. RSC Adv. 2017;7:9669-79.

41. Yang CM, Ferket PR, Hong QH, Zhou J, Cao GT, Zhou L, et al. Effect of chitooligosaccharide on growth performance, intestinal barrier function, intestinal morphology and cecal microflora in weaned pigs. J Anim Sci. 2012;90:2671-6

42. Corthésy B. Role of secretory immunoglobulin a and secretory component in the protection of mucosal surfaces. Future Microbiol. 2010;5:817-29.

43. Keren DF. Intestinal mucosal immune defense mechanisms. Am J Surg Pathol. 1988;12:100-5.

44. Lamont JT. Mucus: the front line of intestinal mucosal defense. Ann N Y Acad Sci. 1992;664:190-201

45. McCauley HA, Guasch G. Three cheers for the goblet cell: maintaining homeostasis in mucosal epithelia. Trends Mol Med. 2015:21:492-503.

46. Linden SK, Sutton P, Karlsson NG, Korolik V, McGuckin MA. Mucins in the mucosal barrier to infection. Mucosal Immunol. 2008;1:183-97.

47. Günther C, Neumann H, Neurath MF, Becker C. Apoptosis, necrosis and necroptosis: cell death regulation in the intestinal epithelium. Gut. 2013;62:1062-71

48. Zhu LH, Cai X, Guo Q, Chen XL, Zhu SW, Xu JX. Effect of N-acetyl cysteine on enterocyte apoptosis and intracellular signalling pathways' response to oxidative stress in weaned piglets. Br J Nutr. 2013;110:1938-47.

49. Zhu LH, Xu JX, Zhu SW, Cai X, Yang SF, Chen XL, et al. Gene expression profiling analysis reveals weaning-induced cell cycle arrest and apoptosis in the small intestine of pigs. J Anim Sci. 2014;92:996-1006.

50. Ghobrial IM, Witzig TE, Adjei AA. Targeting apoptosis pathways in cancer therapy. CA Cancer J Clin. 2005:55:178-94.

51. Hockenbery D, Nuñez G, Milliman C, Schreiber RD, Korsmeyer SJ. BCl-2 is an inner mitochondrial membrane protein that blocks programmed cell death. Nature. 1990;348:334-6.

52. Reed JC, Miyashita T, Takayama S, Wang HG, Sato T, Krajewski S, et al. BCL-2 family proteins: regulators of cell death involved in the pathogenesis of cancer and resistance to therapy. J Cell Biochem. 1996;60:23-32.

53. Zapata JM, Pawlowski K, Haas E, Ware CF, Godzik A, Reed JC. A diverse family of proteins containing tumor necrosis factor receptor-associated factor domains. J Biol Chem. 2001:276:24242-52

54. Elmore S. Apoptosis: a review of programmed cell death. Toxicol Pathol. 2007:35:495-516.

55. Riedl SJ, Shi Y. Molecular mechanisms of caspase regulation during apoptosis. Nat Rev Mol Cell Biol. 2004;5:897-907.

\section{Ready to submit your research? Choose BMC and benefit from:}

- fast, convenient online submission

- thorough peer review by experienced researchers in your field

- rapid publication on acceptance

- support for research data, including large and complex data types

- gold Open Access which fosters wider collaboration and increased citations - maximum visibility for your research: over $100 \mathrm{M}$ website views per year 